\title{
Saline soil enzyme activities of four plant communities in Sangong River basin of Xinjiang, China
}

\author{
ZhengJun GUAN ${ }^{1,2}$, Qian LUO ${ }^{1}$, Xi CHEN $^{3}$, XianWei FENG ${ }^{3}$, ZhiXi TANG $^{1}$, Wei WEl ${ }^{1 *}$, \\ YuanRun ZHENG ${ }^{1}$ \\ ${ }^{1}$ State Key Laboratory of Vegetation and Environmental Change, Institute of Botany, Chinese Academy of Sciences, Beijing \\ 100093, China; \\ ${ }^{2}$ Department of Life Sciences, Yuncheng University, Yuncheng 044000, China; \\ ${ }^{3}$ Xinjiang Institute of Ecology and Geography, Chinese Academy of Sciences, Urumqi 830011, China
}

\begin{abstract}
Soil enzyme activity plays an important role in the conversion of soil organic carbon into inorganic carbon, which is significant for the global carbon cycle. In this study, we investigated the soil enzyme activities of two ligninolytic enzymes (peroxidase and polyphenol oxidase) and five non-ligninolytic enzymes ( $\alpha$-1,4-glucosidase (AG); $\beta$-1,4-glucosidase (BG); $N$-acetyl- $\beta$-glucosaminidase (NAG); $\beta$-D-cellobiosidase (CBH); and $\beta$-xylosidase (BXYL)) in four plant communities of the Sangong River basin in Fukang, North Xinjiang, China. The four typical plant communities were dominated by Haloxylon ammodendron, Reaumuria soongonica, Salsola passerina, and Tamarix rarmosissima, respectively, with saline soils of varied alkalinity. The results showed that the soil peroxidase activity decreased seasonally. The activities of the five non-ligninolytic enzymes decreased with increasing soil depths, while those of the two ligninolytic enzymes did not show such a trend. In the four plant communities, BG had the highest activity among the five non-ligninolytic enzymes, and the activities of the two ligninolytic enzymes were higher than those of the four non-ligninolytic ones (AG, NAG, $\mathrm{CBH}$, and BXYL). The community of $H$. ammodendron displayed the highest activity with respect to the two ligninolytic enzymes in most cases, but no significant differences were found among the four plant communities. The geometric mean of soil enzyme activities of the four plant communities was validated through an independently performed principal component analysis (PCA), which indicated that different plant communities had different soil enzyme activities. The correlation analysis showed that soil polyphenol oxidase activity was significantly positively correlated with the activities of the five non-ligninolytic enzymes. The soil pH value was positively correlated with the activities of all soil enzymes except peroxidase. Soil microbial carbon content also showed a significant positive correlation $(P<0.01)$ with the activities of all soil enzymes except polyphenol oxidase. The results suggested that the $H$. ammodendron community has the highest ability to utilize soil organic carbon, and glucoside could be the most extensively utilized non-ligninolytic carbon source in the saline soil of arid areas in Xinjiang.
\end{abstract}

Keywords: soil enzyme activity; saline soil; Haloxylon ammodendron; Reaumuria soongonica; Salsola passerina; Tamarix rarmosissima

Citation: ZhengJun GUAN, Qian LUO, Xi CHEN, XianWei FENG, ZhiXi TANG, Wei WEI, YuanRun ZHENG. 2014. Saline soil enzyme activities of four plant communities in Sangong River basin of Xinjiang, China. Journal of Arid Land, 6(2): 164-173. doi: 10.1007/s40333-013-0223-6

There are vast areas of arid and semi-arid lands in the world, accounting for one-third of the terrestrial land on the earth (Reynolds et al., 2007). The alkaline-saline soil in arid and semi-arid lands was recently found to play a potentially important role for global $\mathrm{CO}_{2}$ sequestration (Xie et al., 2009; Macías and Arbestain, 2010; Kelley et al., 2011; Ma et al., 2013), although the underground mechanism of the carbon cycle remains unknown. Soil enzyme activity is crucial in the conversion from soil organic carbon to inorganic carbon, which goes in the opposite direction for carbon fixation (Tian et al., 2010; Yang et al., 2012; Jusselme et al., 2013). The study of soil enzyme activity in saline soil is significant for the understanding of the soil carbon cycle in arid and semi-arid areas and thus contributes to research on the global carbon cycle.

\footnotetext{
"Corresponding author: Wei WEI (E-mail: weiwei@ibcas.ac.cn) Received 2013-04-31; revised 2013-07-14; accepted 2013-08-09 (c) Xinjiang Institute of Ecology and Geography, Chinese Academy of Sciences, Science Press and Springer-Verlag Berlin Heidelberg 2014
} 
Xinjiang, located in the hinterland of the Eurasian continent, is characterized by a typical arid climate and has a vast area of saline soil (Li et al., 2010). Plant species in this region mainly include shrubs, semi-shrubs, and small arbors. Among these, Haloxylon ammodendron, Reaumuria soongorica, Salsola passerine and Tamarix rarmosissima are fine plant species exhibiting fast growth and easy propagation for resistance to drought, salinity, and wind erosion or sand burial (Aliasgharzadeh et al., 2001; Ma et al., 2005; Song et al., 2005; Du et al., 2010). In arid and semi-arid ecosystems, different plant communities have various important impacts on the physical-chemical properties of rhizosphere soil, litter decomposition, and the carbon-nitrogen cycle of these ecosystems (Han et al., 2007; Yan et al., 2010). Plant community is a natural link between the soil, atmosphere and moisture, and is an important part of the land-based ecosystems. It can represent the land cover change to a certain extent, and serve as an indicator in the global change researches (DeFries and Townshend, 1994). Thus, research on the soil enzyme activities of typical plant communities in arid and semi-arid areas will be of great significance in understanding the carbon cycle mechanism of the ecosystems.

Soil enzymes, an important component of soil, play an important role in the process of substance circulation and energy exchange in the soil ecosystem (Taylor et al., 2002). The soil enzyme activity reflects the rate of soil nutrient cycling and utilization, and the variety in biological characteristics, and may be an index of soil biodiversity, productivity, and potential microbial activity (Bending et al., 2002, 2004; Sicardi et al., 2004; Williams and Jochem, 2006). In some previous reports, the soil enzyme activity was treated as an important index to evaluate the health and quality of soil (Bending et al., 2004; Bossio et al., 2006), and was also regarded as an indicator of soil remediation in the process of vegetation restoration (Garcia et al., 2000). Some studies have also reported soil enzyme activity and its influencing factors under certain conditions such as different vegetation and soil types and climate change (Salam et al., 1998; Taylor et al., 2002; Alkorta et al., 2003; Micks et al., 2004). However, there are few studies on enzyme activities in saline soil of different plant communities in arid and semi-arid regions. This study aims to evaluate the soil enzyme activities in the salty soil in Xinjiang, China. Four typical plant communities were selected, and their soil enzyme activities and the correlation with soil physical-chemical properties were analyzed. The results will help reveal the process of carbon cycling in arid and semi-arid ecosystems.

\section{Materials and methods}

\subsection{Study area and plant communities}

The study was conducted at the Fukang National Field Scientific Observation and Research Station for Desert Ecosystem, which is located in the Sangong River

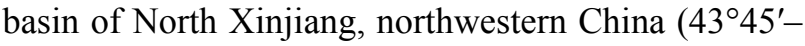
$44^{\circ} 30^{\prime} \mathrm{N}, 87^{\circ} 45^{\prime}-88^{\circ} 05^{\prime} \mathrm{E} ; 450-500 \mathrm{~m}$ asl). The annual mean temperature of the study area is $6.6^{\circ} \mathrm{C}$, with a maximum of $42.6^{\circ} \mathrm{C}$ and a minimum of $-41.6^{\circ} \mathrm{C}$. The average annual frost-free period is 174 days. The average annual precipitation and potential evaporation are $164 \mathrm{~mm}$ and $1,817 \mathrm{~mm}$, respectively. The area is characterized by a typical temperate, arid desert climate. The soil type in this area is saline soil with varied alkalinity.

In May and August of 2011, four representative plant communities dominated respectively by Haloxylon ammodendron (H.a), Reaumuria soongorica (R.s), Tamarix rarmosissima (T.r), and Salsola passerina $(S . p)$ in the study area were selected. These plant communities developed on the same soil type and topography. For each plant community, three $20 \mathrm{~m} \times 20$ $\mathrm{m}$ replicate plots at an interval of $20 \mathrm{~m}$ were set up for further study. Among the four selected plant communities, H.a was the tallest with the widest crown, and $R . s$ was the shortest with a relatively wide crown, while $S . p$ was significantly shorter with the narrowest crown (data not shown). The community cover for H.a, T.r, R.s, and S.p were $72 \%, 65 \%, 59 \%$, and $30 \%$, respectively.

The major companion species in H.a community were ephemeral or annual plants, such as Salsola collina and Ceratocarpus L. (Wang et al., 2009). $R$. soongorica was one of the major dominant species in the arid and alkaline-saline conditions in Xinjiang, and also was the main pasture plant (Chen et al., 2004). Its main root system was not developed and mainly distributed at a $20-40 \mathrm{~cm}$ soil layer ( $\mathrm{Xu}$ and $\mathrm{Li}$, 2009). Compared to R.s, T.r had a strong root system, 
and its branches and leaves could secrete salt. It was one of the main constructive species in arid areas, due to its advantages of strong tolerance to wind erosion, survival ability in sand burial, and high sprouting rate (Yang et al., 2002). In May, no plants were found on the soil surface of $S . p$ community because of high soil salt content. However, in August, S.p plants became vigorous and the total cover increased to $20 \%-40 \%$. Eventually, by October, all the S.p plants died.

\subsection{Soil sampling}

Soil samples were collected in August and October of 2011. Three soil layers in each plot were sampled, at depths of $0-10,10-30$, and $30-70 \mathrm{~cm}$, respectively. In each plot, the entire root system and the associated soil mass were gently pulled out, and the loosely held soil was separated from the roots by hand shaking. Soil samples were placed in plastic bags, transported in a cooler after back to the laboratory, sieved $(<2$ $\mathrm{mm}$ ), and stored at $4^{\circ} \mathrm{C}$ until the physical-chemical and biological properties were analyzed within two weeks.

\subsection{Laboratory analyses}

The electrical conductivity (EC) and $\mathrm{pH}$ value were measured in a 1.0:2.5 soil:water suspension using a Crison Basic 30 conductivity meter and a Crison Basic $20 \mathrm{pH}$ meter, respectively, as described by $\mathrm{Lu}$ (1999). The soil water content was determined by gravimetry and the soil microbial carbon was analyzed in oven-dried samples using a TOC-5000A analyzer.

Two ligninolytic enzymes (peroxidase and polyphenol oxidase) and five non-ligninolytic enzymes ( $\alpha$-1,4-glucosidase (AG); $\beta$-1,4-glucosidase (BG); Nacetyl- $\beta$-glucosaminidase (NAG); $\beta$-D-cellobiosidase $(\mathrm{CBH})$; and $\beta$-xylosidase (BXYL)) were analyzed in this study. Standard methods were used to determine the soil enzyme activities. Peroxidase activity was measured at $450 \mathrm{~nm}$ with 3,3',5,5'-tetramethylbenzidine (TMB) as the substrate according to Johnsen and Jacobsen (2008). The potential activity of polyphenol oxidase was measured at $525 \mathrm{~nm}$ according to the method of Perucci et al. (2000). The activities of AG and BG were measured at $410 \mathrm{~nm}$ (Dick et al., 1996). NAG activity was determined as described by Parham and Deng (2000) and the concentration of para-nitrophenol was measured colorimetrically $(405 \mathrm{~nm})$. The activities of $\mathrm{CBH}$ and BXYL were measured as de- scribed by Miller et al. (1998).

All soil enzyme analyses were determined in quadruplicate against two types of controls (i.e. substrate alone and soil filtrate alone). Soil enzyme activity is expressed as nmol of products produced per hour per gram of soil.

\subsection{Statistical analyses}

All analyses were replicated three times. Statistical analyses were performed using Microsoft Excel 2003 and SPSS version 18.0. Statistically significant differences $(P<0.05)$ were identified using analysis of variance (ANOVA) and Duncan's multiple comparison test. Data were compared using the least significant difference (LSD) test with $P<0.05$ considered to indicate statistical significance. All values were presented as means \pm standard errors. Principal component analysis (PCA) was applied using data for soil enzyme activities and soil physical-chemical properties (Wu et al., 2012; Jusselme et al., 2013). The first two principal components (PC1 and PC2) were selected for further interpretation of the results. Multivariate statistical analyses were performed on the matrices of the soil physical and chemical properties and on soil enzyme activities. The correlation coefficients between the soil enzyme activities and soil physical-chemical properties were interpreted as ordinary Pearson correlation coefficients (Jusselme et al., 2013; Menon et al., 2013).

\section{Results}

\subsection{Soil physical-chemical properties}

The soil $\mathrm{pH}$ levels of the four plant communities were stable (7.84-8.95) at each soil layer during both August and October, with a weak alkalinity and mild hardness (Fig. 1a). Overall, the pH value was higher in October than in August. There were no obvious differences in $\mathrm{pH}$ levels among the four plant communities, or among the different soil layers during both August and October.

The EC in the soil solution can reflect the total amount of soluble salt in the soil. During the same sampling period at the same soil layer, the EC in the soil of S.p community was significantly higher than that of the other three plant communities $(P<0.05$; Fig. 1b). The soil EC of H.a, R.s, and T.r communities were all lowest in the soil layer of $0-10 \mathrm{~cm}$ during 

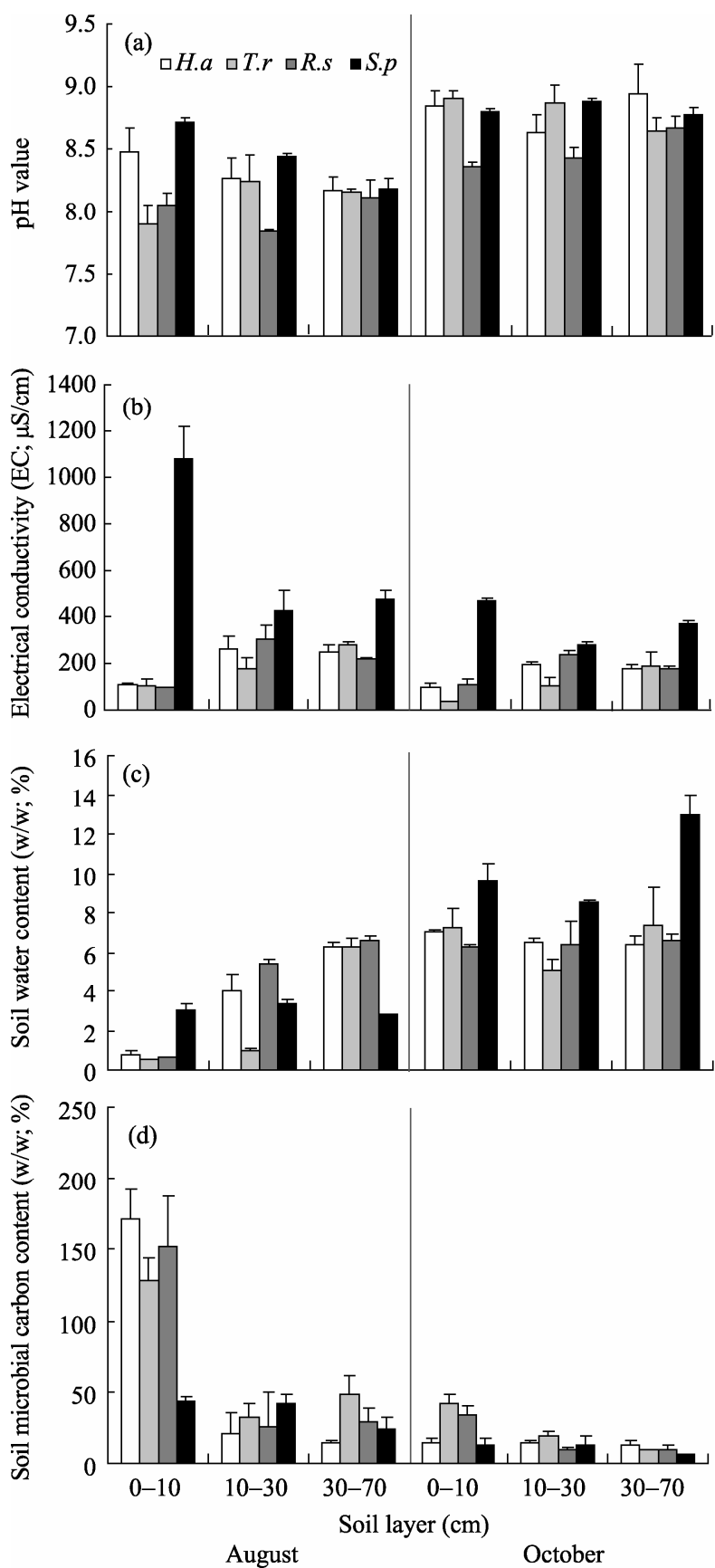

Fig. 1 Soil physical-chemical properties in three soil layers of four plant communities during August and October. H.a, HaloxyIon ammodendron; R.s, Reaumuria soongorica; T.r, Tamarix rarmosissima; S.p, Salsola passerine.

August and October $(P<0.05)$.

For all the four plant communities, the soil water content of the same soil layer was higher in October than in August (Fig. 1c). Compared with the other three plant communities, S. $p$ community had the highest soil water contents $(P<0.05)$ at the $0-10 \mathrm{~cm}$ soil layer during August and at the $30-70 \mathrm{~cm}$ soil layer during October.

The microbial carbon content was highest in the $0-10 \mathrm{~cm}$ soil layer during August, and was present in significant levels in R.s, H.a, and T.r communities (Fig. 1d). Generally, the soil microbial carbon content of each plant community declined with increasing soil depths.

\subsection{Soil enzymatic activities}

\subsubsection{Ligninolytic enzyme activities}

For peroxidase, the enzyme activities in all soil layers of $H . a$ community were higher than those of R.s and T.r communities in August and October $(P<0.05$; Fig. 2a). Soil peroxidase activity of H.a community reached a significant level in the soil layers of $0-10$ and $10-30 \mathrm{~cm}$ in August and $0-10$ and $30-70 \mathrm{~cm}$ in October. All the plant communities showed higher peroxidase activities in each soil layer in August than in October, but exhibited no regular differences between different soil layers.

Similar to these observations with peroxidase activities, there were no overall differences in polyphenol oxidase activities between different soil layers (Fig. 2b). Soil polyphenol oxidase activities of H.a community were significantly higher than those of R.s and T.r
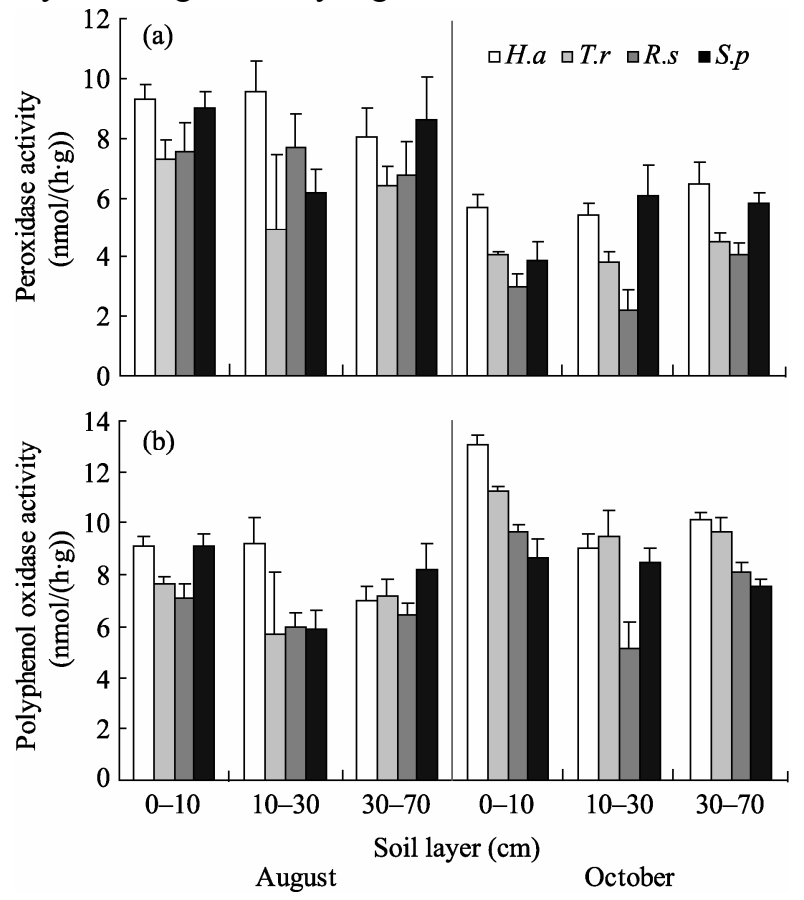

Fig. 2 Peroxidase (a) and polyphenol oxidase (b) activities in three soil layers of four plant communities during August and October 
communities in the soil layer of $0-10 \mathrm{~cm}$ during both August and October, and significantly higher than those of $S . p$ community in both soil layers of $0-10$ and $30-70 \mathrm{~cm}$ during October $(P<0.05)$. The activities of soil polyphenol oxidase of H.a, T.r and R.s communities in the soil layer of $0-10 \mathrm{~cm}$ in October were significant higher than those in the other two layers, and were also higher than those in all layers in August $(P<0.05)$.

2.2.2 Non-ligninolytic enzyme activities

Analyses of the five non-ligninolytic enzymes (NAG, $\mathrm{AG}, \mathrm{CBH}, \mathrm{BG}$, and BXYL) in three soil layers of each plant community showed that the activities of these soil enzymes decreased progressively with increasing soil depths (Figs. 3a-e). In the four plant communities, the activity of BG was higher than those of the other four non-ligninolytic enzymes, whereas the activities of the two ligninolytic enzymes were also higher than those of these four non-ligninolytic ones (NAG, AG, $\mathrm{CBH}$, and BXYL). In August, the activities of the five non-ligninolytic enzymes in the four plant communities were all highest in the soil layer of $0-10 \mathrm{~cm}$, with the maximum soil enzyme activity being observed in $\mathrm{BG}$ and the minimum in NAG (Figs. 3a and d).

In October, the activities of all non-ligninolytic enzymes were again highest in the soil layer of $0-10 \mathrm{~cm}$ (Figs. 3a-e). The activities of the other four non-ligninolytic enzymes, with the exception of NAG, were extremely low or equal to zero in the soil layer of $30-70 \mathrm{~cm}$. In the soil layer of $0-10 \mathrm{~cm}$ during October, the activities of non-ligninolytic enzymes (other than $\mathrm{AG})$ of $H . a$ community were the highest and those (except $\mathrm{CBH}$ ) of R.s community were the lowest among the four plant communities, but differences were not significant.

\subsection{Principal component analysis (PCA)}

PCA was carried out to ascertain the relationships between soil physical-chemical properties and enzyme activities. To examine the variation of soil enzyme activities, only data obtained in the upper soil layer of 0-10 cm were analyzed because soil enzyme activities were primarily distributed in this layer. Eigenvalues from PCA indicated that the first two principal components accounted for $85.62 \%$ of the variance of data (PC1: $51.54 \%$ and PC2: $34.08 \%$; Table 1 and Fig. 4). Both EC and soil water content had a major positive
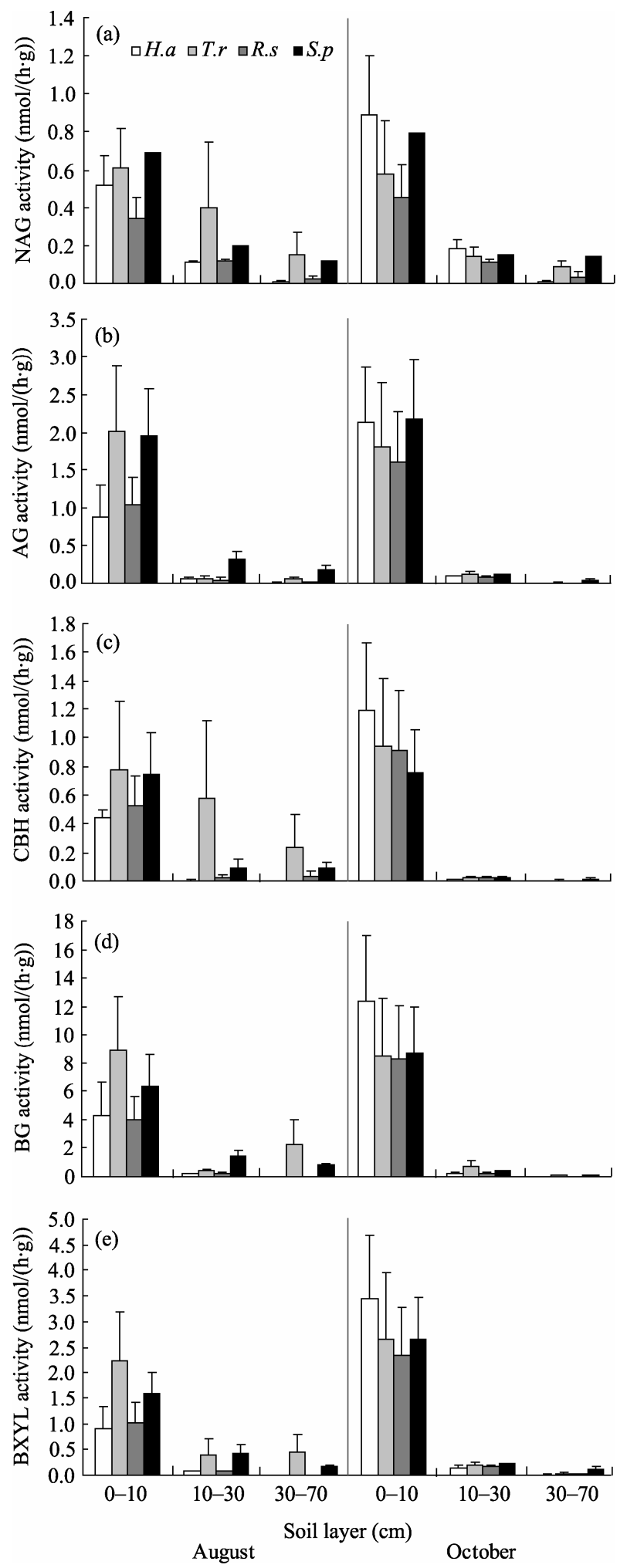

Fig. 3 Activities of five non-ligninolytic enzymes in three soil layers of four plant communities during August and October. (a) NAG, N-acetyl- $\beta$-glucosaminidase; (b) AG, $\alpha$-1,4-glucosidase; (c) $\mathrm{CBH}, \beta$-D-cellobiosidase; (d) BG, $\beta$-1,4-glucosidase; (e) BXYL, $\beta$-xylosidase. 
effect on PC1 (>0.900), while soil microbial carbon content had a negative effect on PC1 $(>0.900)$. Moreover, the activities of polyphenol oxidase, $\mathrm{CBH}, \mathrm{BG}$, and BXYL had a major positive effect on PC2 $(>0.800)$. The soil enzyme activities of H.a and T.r communities, independently located in the second quadrant of the PCA ordination diagram, were different to those of the other two plant communities. Soil $\mathrm{pH}$ value was positively related to almost all of the soil enzyme activities, while soil EC was negatively related to almost all of the soil enzyme activities.

Table 1 Rotated component matrix by factor analysis for the soil enzyme activities of four plant communities

\begin{tabular}{ccc}
\hline Component & PC1 & PC2 \\
\hline $\mathrm{pH}$ & 0.775 & 0.529 \\
$\mathrm{EC}$ & 0.979 & -0.192 \\
Soil water content & 0.999 & -0.019 \\
Soil microbial carbon content & -0.988 & 0.118 \\
Peroxidase & 0.276 & 0.690 \\
Polyphenol oxidase & -0.169 & 0.865 \\
NAG & 0.705 & 0.681 \\
AG & 0.771 & 0.332 \\
CBH & -0.214 & 0.890 \\
BG & 0.098 & 0.959 \\
BXYL & 0.211 & 0.864 \\
\hline
\end{tabular}

Note: Rotation converged in 4 iterations. Extraction method: principal component analysis; rotation method: varimax with Kaiser normalization.

\subsection{Relationships between soil physical-chemical properties and soil enzyme activities}

Correlation analysis showed that there was no significant correlation between the activities of soil peroxidase and the five non-ligninolytic enzymes (Table 2). However, soil polyphenol oxidase activity was significantly and positively correlated with the five nonligninolytic enzyme activities. Additionally, there was an extremely significant and positive correlation among the five non-ligninolytic enzymes. Further, the activities of BXYL and BG had the highest correlation coefficient $(0.969, P<0.01)$. The results implicated that the soil enzyme activities might be affected by the similar environmental factors.

Correlation analysis among the four soil physical-chemical properties indicated that soil microbial carbon content was negatively correlated to the other three properties, with extremely significant negative correlation with $\mathrm{pH}$ value $(-0.304, P<0.01)$ and soil water content $(-0.601, P<0.01)$. Moreover, soil water content had extremely significant positive correlation with $\mathrm{pH}$ value $(0.420, P<0.01)$.

The relationships between the soil physical-chemical properties and soil enzyme activities were determined in this study (Table 3). The results indicated that $\mathrm{pH}$ value was positively correlated with polyphenol oxidase activity at an extremely significant level $(0.542$, $P<0.01$ ). Soil EC had a significant positive correlation

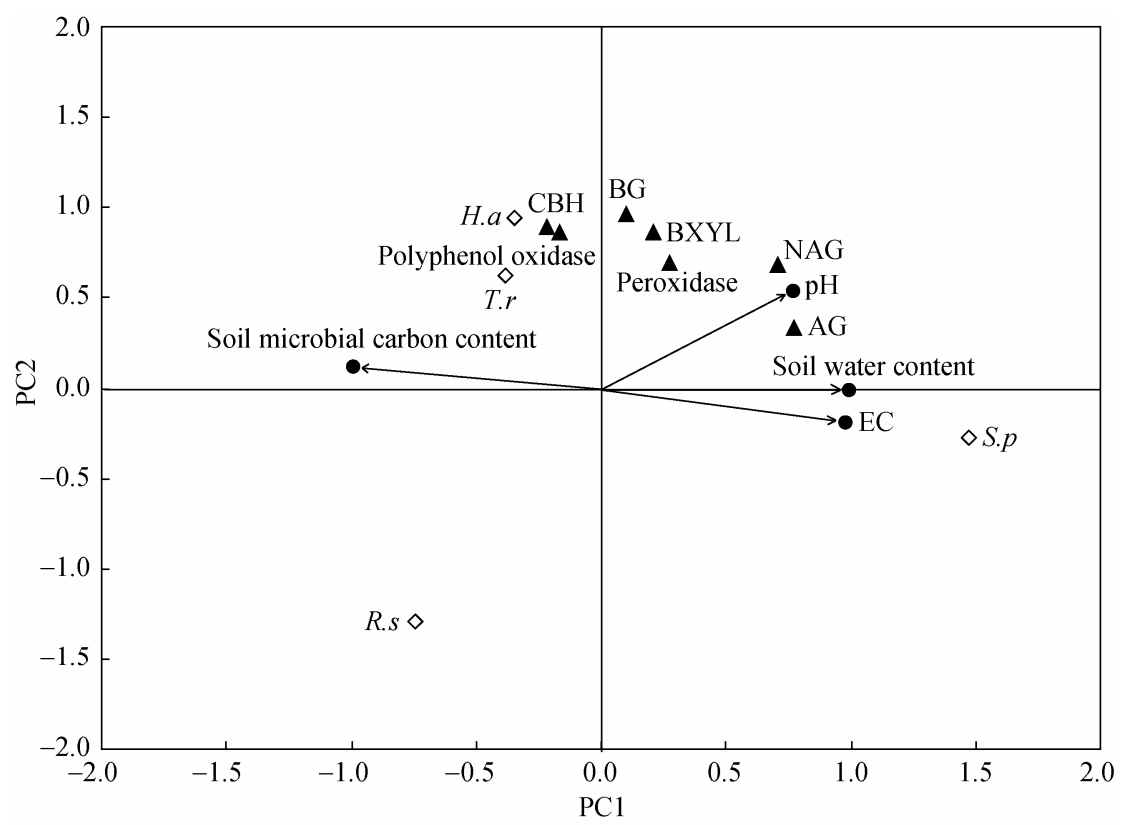

Fig. 4 Principal component analysis (PCA) of the soil physical-chemical properties and soil enzyme activities of four plant communities 
Table 2 Correlation coefficients among the seven soil enzyme activities $(n=96)$

\begin{tabular}{cccccccc}
\hline & Peroxidase & Polyphenol oxidase & NAG & AG & CBH & BG & BXYL \\
\hline Peroxidase & 1.000 & 0.105 & -0.025 & 0.005 & -0.050 & -0.015 & -0.099 \\
Polyphenol oxidase & & 1.000 & $0.321^{* *}$ & $0.387^{* *}$ & $0.330^{* *}$ & $0.419^{* *}$ & $0.435^{* *}$ \\
NAG & & & 1.000 & $0.906^{* *}$ & $0.873^{* *}$ & $0.869^{* *}$ & $0.897^{* *}$ \\
AG & & & 1.000 & $0.908^{* *}$ & $0.951^{* *}$ & $0.954^{* *}$ \\
CBH & & & & 1.000 & $0.922^{* *}$ & $0.935^{* *}$ \\
BG & & & & & 1.000 & $0.969^{* *}$ \\
BXYL & & & & & & & 1.000 \\
\hline
\end{tabular}

Note: ${ }^{* *}$ indicates significance at the 0.01 level.

Table 3 Correlation coefficients between soil physical-chemical properties and soil enzyme activities ( $n=96)$

\begin{tabular}{ccccccccc}
\hline & Peroxidase & polyphenol oxidase & NAG & AG & CBH & BG & BXYL \\
\hline pH & -0.195 & $0.542^{* *}$ & 0.091 & 0.052 & 0.021 & 0.036 \\
EC & $0.251^{*}$ & -0.132 & 0.123 & 0.079 & -0.009 & -0.019 & -0.026 \\
Soil water content & $-0.402^{* *}$ & 0.147 & -0.106 & -0.095 & -0.100 & -0.041 \\
Soil microbial carbon content & $0.402^{* *}$ & -0.028 & $0.317^{* *}$ & $0.336^{*}$ & $0.329^{* *}$ & $0.297^{*}$ & $0.237^{*}$ \\
\hline
\end{tabular}

Note: ${ }^{*}$ and ${ }^{* *}$ indicate significance at the 0.05 level and 0.01 level, respectively.

with peroxidase activity $(P<0.05)$, while soil water content had a significant negative correlation with peroxidase activity $(P<0.01)$. Soil microbial carbon content had a significant $(P<0.05)$ or extremely significant $(P<0.01)$ positive correlation with the activities of all soil enzymes except polyphenol oxidase.

\section{Discussion}

Differences in different soil enzyme activities and in soil physical-chemical properties were studied in the saline soil of four typical plant communities in the Sangong River basin in Xinjiang, which might contribute to the researches of different utilization of carbon sources in this area (Luo et al., 2013). H. ammodendron, as a shrub or small tree, has a simple community structure. Its developed root system may display significant "fertile island" effects such as enriching soil nutrients to ensure the viability of $H . a$ in extremely dry areas (Hu, 1985; Yang et al., 1991; Liu et al., 2010). This is consistent with the findings of our study. H. ammodendron community showed higher soil peroxidase and polyphenol oxidase activities, and its four non-ligninolytic enzyme activities (NAG, $\mathrm{CBH}, \mathrm{BG}$, and $\mathrm{BXYL}$ ) were also higher in the surface soil layer of $0-10 \mathrm{~cm}$ during October. $R$. soongonica could strongly adapt to the desertified, drought, and high-salt environment (Cui, 1988), and its soil in the $10-30 \mathrm{~cm}$ depth showed high total salt content (Chen et al., 2004). Similar results were also obtained in our study that the EC of R.s community reached a maximum value in the soil layer of $10-30 \mathrm{~cm}$. The results of PCA showed that PC1 best reflected the soil enzyme activities of H.a community. S. passerina community had higher $\mathrm{pH}$ value and $\mathrm{EC}$ value as well as relatively high soil water content, which was presumably related to the characteristics of ephemeral plants and resulted in high soil enzyme activities during the growth season. Previous studies have suggested that the H.a community has the highest ability to utilize soil organic carbon (Luo et al., 2013), which was confirmed here in this study.

Our result showed that the activities of five nonligninolytic enzymes gradually decreased with increasing soil depths, which was consistent with other related studies (e.g. Burger and Kelting, 1999; Spear et al., 2001; Taylor et al., 2002). The vertical distribution characteristics of soil enzyme activity reflect the degree of soil disturbance (Burns and Dick, 2001). The best explanation for our result is that the topsoil was better able to exchange substances and energy with the atmosphere, and the organic matter absorbed into soil was first gathered in the surface soil layer and thus the surface soil exhibited better nutrient conditions and vigorous microbial and soil enzyme activities (Tan et al., 2011, 2012).

The soil enzyme activities of different plant com- 
munities had certain seasonal variation characteristics. Niemi et al. (2005) suggested that the soil enzyme activities vary seasonally, which depends on the chemical, physical, and biological characteristics of the soil. Wu et al. (2012) analyzed soil enzyme activities in the permafrost regions of the Western Qinghai-Tibetan Plateau and found that soil temperature had a less important effect on soil enzyme activities, which indicated that soil enzyme activities were primarily affected by environmental factors other than seasonal variations. In our study, polyphenol oxidase activities in all soil layers were higher in October than in August, whereas in the soil layer of $0-10 \mathrm{~cm}$, the activities of the five non-ligninolytic enzymes were significantly higher in October than in August. Previous studies have suggested that the peak of soil enzyme activity does not always appear in the season of higher temperature (Sinsabaugh et al., 1993; Harris and Safford, 1996; Burger and Kelting, 1999; Criquet et al., 2003).

Soil enzymes are the products of vital activity in the soil, and their activities may reflect the states of soil biological metabolism and material transformation. Thus, soil enzymes are an overall indicator of soil biological activity (Alkorta et al., 2003). In our study, BG had the highest activity among the five non-ligninolytic enzymes for all plant communities. Therefore, it suggested that BG could most extensively utilize the non-ligninolytic carbon sources in the saline soil of arid areas in Xinjiang. In addition, studies have shown that increased soil enzyme activities were closely associated with the improvement of soil environments ( $\mathrm{Su}$ et al., 2005). Differences in salinity and alkalinity in the soil could affect the activities of soil enzymes. The relationships between soil physical-chemical properties and soil enzyme activities indicated that soil physical and chemical properties may affect soil enzyme activities. Soil EC was negatively correlated with most of the soil enzyme activities in our study; in contrast, soil $\mathrm{pH}$ value was positively correlated with all the soil enzyme activities except in the case of peroxidase.

The major impact of plant species on the activities of carbon cycle related soil enzymes was demonstrated for peroxidase and polyphenol oxidase, as the activities of these soil enzymes decreased in certain plant community. Both peroxidase and polyphenol oxidase are involved in the mineralization of lignin and phenolic materials. Environmental factors such as soil $\mathrm{pH}$ value and nitrogen availability may affect soil peroxidase and polyphenol oxidase activities (Sinsabaugh et al., 1993). Our results showed that soil peroxidase activity was significantly related to the soil physical-chemical properties except $\mathrm{pH}$ value, while soil polyphenol oxidase activity was only significantly correlated with $\mathrm{pH}$ value. The activities of NAG, AG and BG are affected by the supply of carbon and nutrients to the soil via root turnover (Shackle et al., 2000; Jackson and Vallaire, 2009). The activities of these three non-ligninolytic enzymes in wetlands have been found to be negatively correlated to the soil EC (Menon et al., 2013), which is different to our results. In our study, among the four soil physical-chemical properties, only soil microbial carbon content significantly affected the five non-ligninolytic enzyme activities, probably due to the short-term duration of our study. Future long-term studies will be necessary to monitor changes in the soil enzyme activities in the presence of various plant communities.

\section{Conclusions}

Soil enzyme activities related to carbon cycle and their correlation with soil physical-chemical properties in four typical plant communities of arid land in Xinjiang were analyzed in this study. The findings showed that the activities of the five non-ligninolytic enzymes (NAG, AG, CBH, BG, and BXYL) decreased with increasing soil depths. BG had the highest activity among the five non-ligninolytic enzymes in the four plant communities. The soil polyphenol oxidase activity had significant positive correlation with the activities of the five non-ligninolytic enzymes. In the four soil physical-chemical properties, only soil microbial carbon content had a significant positive correlation with the activities of the five non-ligninolytic enzymes. Except the $S$. passerine community with high alkalinity, EC and soil water content, H. ammodendron community has potentially highest soil enzyme activities among the other three plant communities. The research result will help to understand the process of nutrient cycling in arid and semi-arid ecosystems. 


\section{Acknowledgement}

This work was funded by the National Basic Research Program of China (2009CB825103), the National Natural Science Foundation of China (31200422), and China's Postdoctoral Science Foundation (2012M520455, 2013T60193).

\section{References}

Aliasgharzadeh N, Rastin S N, Towfighi H, et al. 2001. Occurrence of arbuscular mycorrhizal fungi in saline soils of the Tabriz Plain of Iran in relation to some physical and chemical properties of soil. Mycorrhiza, 11(3): 119-122.

Alkorta I, Aizpurua A, Riga P, et al. 2003. Soil enzyme activities as biological indicators of soil health. Reviews on Environmental Health, 18(1): 65-73.

Bending G D, Turner M K, Jones J E. 2002. Interactions between crop residue and soil organic matter quality and the functional diversity of soil microbial communities. Soil Biology and Biochemistry, 34(8): 1073-1082.

Bending G D, Turner M K, Rayns F, et al. 2004. Microbial and biochemical soil quality indicators and their potential for differentiating areas under contrasting agricultural management regimes. Soil Biology and Biochemistry, 36(11): 1785-1792.

Bossio D A, Fleck J A, Scow K M, et al. 2006. Alteration of soil microbial communities and water quality in restored wetlands. Soil Biology and Biochemistry, 38(6): 1223-1233.

Burger J A, Kelting D L. 1999. Using soil quality indicators to assess forest stand management. Forest Ecology and Management, 122(1-2): 155-166.

Burns R G, Dick R P. 2001. Enzymes in the Environment: Activity, Ecology, and Applications. New York: MarcelDekker, Inc.

Chen Y, Wang H, Zhang F S, et al. 2004. Ions secretion in wild Reaumuria soongorica under natural saline-alkall conditions. Acta Pedologica Sinica, 41(5): 774-779.

Criquet S, Farnet A M, Tagger S. 2000. Annual variations of phenoloxidase activities in an evergreen oak litter influence of certain biotic and abiotic factors. Soil Biology and Biochemistry, 32(11-12): 1505-1513.

Cui D F. 1988. Studies on classification, distribution, ecology and morphological observation of Reaumuria soongorica in China. Arid Zone Research, 5(1): 65-69.

DeFries R S, Townshend J R G. 1994. NDVI-derived land cover classifications at a global scale. International Journal Remote Sensing, 15(17): 3567-3586.

Dick R P, Breakwell D P, Turco R F. 1996. Soil enzyme activities and biodiversity measurements as integrative microbiological indicators. In: Doran J W, Jones A J. Methods of Assessing Soil Quality. Madison: Soil Science Society of America, 247-271.

Du J H, Yan P, Dong Y X. 2010. The progress and prospects of nebkhas in arid areas. Journal of Geographical Sciences, 20(5): 712-728.

Garcia C, Hernandez T, Roldan A, et al. 2000. Organic amendment and mycorrhizal inoculation as a practice in afforestation of soils with Pinus halepensis Miller: effect on their microbial activity. Soil Biology and Biochemistry, 32(8-9): 1173-1181.
Han X M, Wang R Q, Liu J, et al. 2007. Effects of vegetation type on soil microbial community structure and catabolic diversity assessed by polyphasic methods in North China. Journal of Environmental Sciences, 19(10): 1228-1234.

Harris M M, Safford L O. 1996. Effect of season and four tree species on soluble carbon content in fresh and decomposing litter of temperate forests. Soil Science, 161(2): 130-135.

Hu W K. 1985. The productivity evaluation and reasonable development way of Haloxylon ammodendron desert in southern Dzungarian Basin. Arid Zone Research, 2(2): 40-45.

Jackson C R, Vallaire S C. 2009. Effects of salinity and nutrients on microbial assemblages in Louisiana wetland sediments. Wetlands, 29(1): 277-287.

Johnsen A R, Jacobsen O S. 2008. A quick and sensitive method for the quantification of peroxidase activity of organic surface soil from forests. Soil Biology and Biochemistry, 40(3): 814-821.

Jusselme M D, Miambi E, Mora P, et al. 2013. Increased lead availability and enzyme activities in root-adhering soil of Lantana camara during phytoextraction in the presence of earthworms. Science of The Total Environment, 445-446: 101-109.

Kelley A M, Fay P A, Polley H W, et al. 2011. Atmospheric $\mathrm{CO}_{2}$ and soil extracellular enzyme activity: a meta-analysis and $\mathrm{CO}_{2}$ gradient experiment. Ecosphere, 2(8): 1-20.

Li Z Z, Wu S L, Chen D J. 2010. Bio-geomorphologic features and growth process of Tamarix nabkhas in Hotan River Basin, Xinjiang. Journal of Geographical Sciences, 20(2): 205-218.

Liu Y H, Yang Y L, Sheng J D, et al. 2010. 'Fertile island' characteristics of soil nutritions in Haloxylon ammodendron land in North Xinjiang. Acta Pedologica Sinica, 47(3): 545-554.

Lu R K 1999. Method of Analysis in Soil and Agrochemistry. Beijing: China Agricultural Press.

Luo Q, Huang B L, Tang Z X, et al. 2013. Carbon source utilization of microbes in saline soil of three vegetation types in Xinjiang, China. Chinese Journal of Applied \& Environmental Biology, 19(1): 96-104.

Ma J, Wang Z Y, Stevenson B A, et al. 2013. An inorganic $\mathrm{CO}_{2}$ diffusion and dissolution process explains negative $\mathrm{CO}_{2}$ fluxes in saline/alkaline soils. Scientific Reports, 3, doi:10.1038/srep02025.

Ma J Y, Chen T, Qiang W Y, et al. 2005. Correlations between foliar stable carbon isotope composition and environmental factors in desert plant Reaumuria soongorica (Pall.) Maxim. Journal of Integrative Plant Biology, 47(9): 1065-1073.

Macías F, Arbestain M C. 2010. Soil carbon sequestration in a changing global environment. Mitigation and Adaptation Strategies for Global Change, 15(6): 511-529.

Menon R, Jackson C R, Holland M M. 2013. The influence of vegetation on microbial enzyme activity and bacterial community structure in freshwater constructed wetland sediments. Wetlands, 33(2): 365378.

Micks P, Downs M R, Magill A H, et al. 2004. Decomposing litter as a sink for ${ }^{15} \mathrm{~N}$-enriched additions to an oak forest and a red pine plantation. Forest Ecology and Management, 196(1): 71-87.

Miller M, Palojarvi A, Rangger A, et al. 1998. The use of fluorgenic substrates to measure fungal presence and activity in soil. Applied 
Environmental Microbiology, 64(2): 613-617.

Niemi R M, Vepsäläinen M, Wallenius K, et al. 2005. Temporal and soil depth-related variation in soil enzyme activities and in root growth of red clover (Trifolium pratense) and timothy (Phleum pratense) in the field. Applied Soil Ecology, 30(2): 113-125.

Parham J A, Deng S P. 2000. Detection, quantification, and charaterization of $\beta$-glucosaminadase activity in soils. Soil Biology and Biochemistry, 32(8-9): 1183-1190.

Perucci P, Casucci C, Dumontet S. 2000. An improved method to evaluate the $o$-diphenol oxidase activity of soil. Soil Biology and Biochemistry, 32(13): 1927-1933.

Reynolds J F, Stafford Smith D M, Lambin E F, et al. 2007. Global desertification: building a science for dryland development. Science, 316(11): 847-851.

Salam A K, Katayama A, Kimura M. 1998. Activities of some soil enzymes in different land use system after deforestation in hilly areas of west Lampungm, South Sumatra, Indonesia. Soil Science and Plant Nutrition, 44(1): 93-103.

Shackle V J, Freeman C, Reynolds B. 2000. Carbon supply and the regulation of enzyme activity in constructed wetlands. Soil Biology and Biochemistry, 32(13): 1935-1940.

Sicardi M, García-Préchac F, Frioni L. 2004. Soil microbial indicators sensitive to land use conversion from pastures to commercial Eucalyptus grandis (Hill ex Maiden) plantations in Uruguay. Applied Soil Ecology, 27(2): 125-133.

Sinsabaugh R L, Antibus R K, Linkins A E, et al. 1993. Wood decomposition: nitrogen and phosphorus dynamics in relation to extracellular enzyme activity. Ecology, 74(5): 1586-1593.

Song J, Feng G, Tian C Y, et al. 2005. Strategies for adaptation of Suaeda physophora, Haloxylon ammodendron and Haloxylon persicum to a saline environment during seed-germination stage. Annals of Botany, 96(3): 399-405.

Spears J D H, Lajtha K, Caldwell B A, et al. 2001. Species effects of Ceanothus relutinus versus Pseudotsuga menziesii, Douglas-fir, on soil phosphorus and nitrogen properties in the Oregon cascades. Forest Ecology and Management, 149(1-3): 205-216.

Su Y Z, Li Y L, Cui J Y, et al. 2005. Influences of continuous grazing and livestock exclusion on soil properties in a degraded sandy grassland, Inner Mongolia, Northern China. Catena, 59(3): 267-278.

Tan B, Wu F Z, Yang W Q, et al. 2011a. Soil biochemical dynamics at three elevations during the soil thawing period, Eastern Tibetan
Plateau: nutrient availabilities, microbial properties and enzyme activities. African Journal of Microbiology Research, 6(22): 47124721.

Tan B, Wu F Z, Yang W Q, et al. 2011b. The dynamics pattern of soil carbon and nutrient as soil thawing proceeded in the alpine/subalpine forest. Acta Agriculture Scandinavica: Soil \& Plant Science, 61(7): $670-679$.

Taylor J P, Wilson B, Mills M S, et al. 2002. Comparison of microbial numbers and enzymatic activities in surface soils and subsoils using various techniques. Soil Biology and Biochemistry, 34(3): 387-401.

Tian L, Dell E, Shi W. 2010. Chemical composition of dissolved organic matter in agroecosystems: correlations with soil enzyme activity and carbon and nitrogen mineralization. Applied Soil Ecology, 46(3): 426-435.

Wang L J, Zhao C Y, Li J, et al. 2009. Study on the early-spring species diversity in a Haloxylon desert in the North Fukang region, Xinjiang. Arid Zone Research, 26(4): 574-581.

Williams C J, Jochem F J. 2006. Ectoenzyme kinetics in Florida Bay: Implications for bacterial carbon source and nutrient status. Hydrobiology, 569(1): 113-127.

Wu X D, Zhao L, Fang H B, et al. 2012. Soil enzyme activities in permafrost regions of the western Qinghai-Tibetan Plateau. Soil Science Society of America Journal, 76(4): 1280-1289.

Xie J X, Li Y, Zhai C X, et al. 2009. $\mathrm{CO}_{2}$ absorption by alkaline soils and its implication to the global carbon cycle. Environmental Geology, 56(5): 953-961.

Xu G Q, Li Y. 2009. Roots distribution of three desert shrubs and their response to precipitation under co-occurring conditions. Acta Ecologica Sinica, 29(1): 130-137.

Yan H Y, Gu X R, Shen H. 2010. Microbial decomposition of forest litter: a review. Chinese Journal of Ecology, 29(9): 1827-1835.

Yang C M, Wang M M, Li J H. 2012. Influence of rhizosphere microbial ecophysiological parameters from different plant species on butachlor degradation in a riparian soil. Journal of Environmental Quality, 41(3): 716-723.

Yang W B, Bao X F, Yang M R, et al. 1991. Research on relationship of physio-ecological water to droughy resistance for Saxaul. Acta Ecologica Sinica, 11(4): 318-323.

Yang W K, Zhang D Y, Yin L K, et al. 2002. Distribution and cluster analysis on the similarity of the Tamarix communities in Xinjiang. Arid Zone Research, 19(3): 6-11. 